\title{
DO YOU KNOW THE WORD? SEBUAH STUDI TENTANG LEVEL KOSAKATA PADA MAHASISWA BARU
}

\author{
Do you know the word? A Study on vocabulary level of freshman) \\ Oleh : Boni Saputra*) \\ E-mail : bonisaputra@polbeng.ac.id \\ *) Program Studi D3 Bahasa Inggris Politeknik Negeri Bengkalis
}

\begin{abstract}
Vocabulary is part of language teaching and learning. Sufficient words usage ease students cope with academic assignments. This study tries to find out vocabulary level of freshman at English department State Polytechnic of Bengkalis. The method of the research is descriptive. Instruments used in gathered the data is set of vocabulary level test designed by Nation (1983) and developed by Schmitt, N., D. Schmitt, and C. Clapham. 2001. The population of the study is 16 freshman of Diploma program. The result of the test showed that most of the students are below 1000 vocabulary level. The finding revealed that the learners have limited vocabulary. It also brings two implications to the teaching. First, Lecturers should provide ekstra vocabulary training in lessons. Then, instruction language used should be adjusted between target language and mother tongue.
\end{abstract}

Key words: Vocabulary level, training, instruction language 


\section{PENDAHULUAN}

Pembelajaran kosakata adalah salah satu bagian penting dalam penguasaan Bahasa. Level kosakata yang memadai sangat membantu dalam proses belajar bahasa dan pengembangan kemampuan pelajar dalam bahasa yang dipelajari. Penguasaan kosakata yang baik adalah dasar kemampuan berkomunikasi lisan dan tulisan untuk membuat kalimat, mengungkapkan ide yang mereka miliki. Thornbury (2002), mengatakan bahwa kemampuan tata bahasa yang baik sekalipun harus didukung oleh penguasaan kosakata yang cukup. Sementara Fahrudin dan Fakhruddin \& jamaris, m (2005) juga berpendapat bahwa kosakata mencerminkan kemampuan berbahasa atau linguistik seseorang. Disisi lain Harmer (2001) menjelaskan bahwa dalam linguistik terapan kosakata menjadi komponen pertama yang mempengaruhi pembelajar bahasa. Dengan kata lain, orang yang mampu menggunakan level kosakata tertentu menunjukkan kemampuan berbahasanya. Oleh karena itu hal ini sangat penting dalam meningkatkan skill berbahasa setiap individu pembelajar. Hal ini menjadi lebih urgen bagi mahasiswa karena tantangan perkuliahan yang menuntut untuk membuat tugas-tugas dalam penyelesaian kuliah mereka.

Kosakata dapat di artikan beragam. Barnhart (2008) mengartikan "kosakata sebagai kumpulan kata yang digunakan oleh orang, golongan, profesi, dan lainlain. Kumpulan atau daftar kata, biasanya berurutan abjad dan ditentukan. Selain itu, kosakata diartikan sebagai jumlah total kata dengan makna dan definisi yang digunakan oleh seseorang untuk mengungkapkan ide dalam bahasa". Sedangkan Soedjito (2009) mengatakan kosakata adalah seluruh kata pembentuk suatu bahasa. Ini juga bisa diartikan perbendaharaan kata yang dimiliki oleh seorang untuk berbicara atau menulis. Selain itu, kata-kata yang digunakan dalam bidang tertentu. Dapat disimpulkan bahwa, kosakata adalah keseluruhan kata dalam sebuah bahasa yang di pakai orang atau kelompok orang tertentu di bidang tertentu pula.

Kosakata sangat esensial untuk dipelajari, tetapi juga menantang bagi pembelajar dan pendidik. Kosakata merupakan salah satu tantangan dalam belajar bahasa Inggris; banyak orang yang belajar tidak memiliki cukup kosakata. Diyanti (2003) menyatakan bahwa kosakata membantu siswa memahami informasi yang mereka dapat. Oleh karena itu, kosakata adalah bagian integral dalam keseluruhan proses belajar mengajar bahasa Inggris. Sedangkan menurut Thornburry (2002) belajar kosakata dapat dimulai dari kosakata sederhana yang umum digunakan sehari-hari; walaupun terdapat berbagai jenis kosakata tergantung konteks dan penggunaan di berbagai bidang. Kemampuan ini bisa dipelajari secara natural oleh anak didik melalui latihan. Diyanti (2003) mengingatkan pentingnya memfasilitasi siswa sehingga mandiri dalam mempelajari vocabulary. Kegiatan pembelajaran sebaiknya bisa terapkan sendiri dimanapun oleh mereka. Pendidik mesti memberikan kebebasan untuk anak didik dalam mempelajarinya. Eksplorasi yang dilakukan dalam kegiatan menggunakan media dapat mempertahankan ingatan tentang kosakata dalam waktu yang lama.

Meskipun kenyataan kosakata ini penting sebagai elemen utama dalam pembelajaran dan penggunaan bahasa, peserta didik masih menghadapi kesulitan mempelajarinya. Beberapa sulit mengingat kosakata karena kurang berlatih menggunakannya. Hal ini juga terjadi pada mahasiswa baru jurusan Bahasa Politeknik Negeri Bengkalis. Dari pengalaman tahuntahun yang lalu, hanya sebagian yang memiliki Level kosakata yang mumpuni saat masuk. Untuk itu diperlukan Pre-test awal level kosakata mereka dimiliki. Ini penting untuk menentukan sejauh mana kemampuan mereka yang berimplikasi pada starting poin pembelajaran berbagai mata kuliah dan metode yang lebih tepat 
untuk digunakan. Oleh karena itu perlu di rumuskan pertanyaan dalam penelitian ini yakni ; Bagaimana kemampuan kosakata Mahasiswa Baru Jurusan Bahasa Politeknik Negeri Bengkalis?

\section{METODE PENELITIAN}

Penelitian ini adalah sebuah penelitian deskriptif. Gay (2000) mengatakan bahwa studi deskriptif bertujuan untuk menentukan dan menjelaskan keadaan yang sebenarnya terjadi. Tujuan penelitian ini adalah mengetahui intake level vocabulary mahasiswa semester 1 program studi D3 Bahasa Inggris Politeknik Negeri Bengkalis. Adapun instrumen yang dipakai adalah vocabulary level test yang di kembangkan oleh Nation, I.S.P. 1983. Testing and teaching vocabulary. Guidelines 5, no. 1: 12-25 dan Schmitt, N., D. Schmitt, and C. Clapham Tes ini terdiri dari level 1000 dan 2000 kata. Namun dalam penelitian ini peneliti hanye menggunakan level maksimal 1000 yang terdiri dari 30 soal.

\section{HASIL}

Seperti dijelaskan pada poin sebelumnya, penelitian ini bertujuan untuk mendapatkan informasi tentang level kemampuan kosakata pada mahasiswa baru jurusan Bahasa Politeknik Negeri Bengkalis. Untuk memperoleh hasil penelitian sesuai dengan tujuan dari penelitian tersebut, Peneliti telah melaksanakan tes level kosakata (vocabulary level test) dengan menggunakan tes yang dbuat oleh nunan.

Sebanyak 16 orang sample mahasiswa baru yang telah diambil melalui total sampling telah mengikuti tes level kosakata. Adapun secara detail kemampuan nya dapat dilihat dari tabel berikut:

Tabel 1. Kemampuan Mahasiswa

\begin{tabular}{|l|l|l|}
\hline No & Students & Level \\
\hline 1 & Iha Farorah & 700 \\
\hline 2 & Dinda Leonita Rizky & 866 \\
\hline 3 & Melisa Elfianti & 833 \\
\hline
\end{tabular}

\begin{tabular}{|l|l|l|}
\hline 4 & Beni Situmorang & 900 \\
\hline 5 & Mhd indrawan & 833 \\
\hline 6 & Rosinitta Janlena & 800 \\
\hline 7 & Deni Wijaya & 800 \\
\hline 8 & Asya ayu sridewi & 900 \\
\hline 9 & Yuni atika sari & 866 \\
\hline 10 & Estin Telaumbanua & 700 \\
\hline 11 & $\begin{array}{l}\text { Muhammad } \\
\text { Syahreza }\end{array}$ & 866 \\
\hline 12 & Suci Ramadina & 900 \\
\hline 13 & Mutia Wulan Dari & 900 \\
\hline 14 & $\begin{array}{l}\text { Mutia Nova } \\
\text { Syahputri }\end{array}$ & 1000 \\
\hline 15 & Surya Wahyu Putra & 1000 \\
\hline 16 & Norisa & 1000 \\
\hline
\end{tabular}

Dari tabel diatas dapat dilihat secara umum kemampuan mahasiswa baru jurusan bahasa berada dibawah level seribu kata. Namun demikian semua mahasiswa berada diatas level 700 kata. Bahkan ada beberapa dapat mencapai level 1000 kata.

\section{PEMBAHASAN}

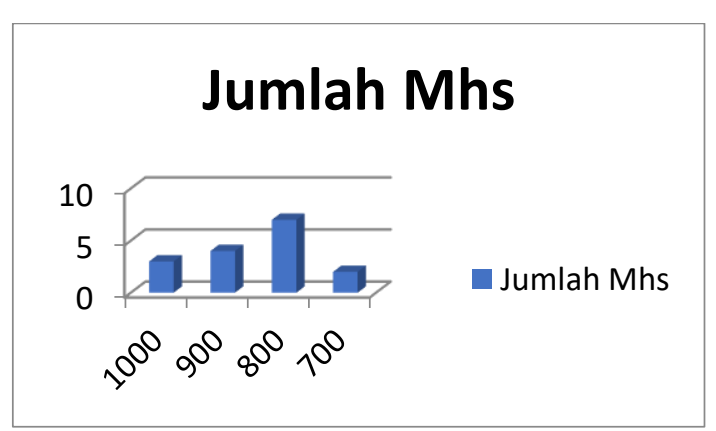

Grafik 1. Jumlah Mahasiswa

Grafik diatas lebih detail mengggambarkan level kosakata mahasiswa. Sebagian besar mahasiswa yaitu 7 orang atau $43,75 \%$ berada pada level 800 kata. 4 orang atau $25 \%$ mendapatkan nilai 900. Lalu 3 orang atau $18,75 \%$ berada pada level 1000 kata. Hanya 2 orang atau 12,5\% mendapat nilai 700. Hasil ini mengindikasikan bahwa intake level vocabulary mahasiswa baru masih rendah. Adapun rata-rata nilai mahasiswa berada pada 866,5 kata. Mahasiswa terutama dengan level kosakata dibawah seribu belum cukup mumpuni dan memerlukan training tambahan dalam 
menyelesaikan tugas-tugas akademik perkuliahan

\section{IMPLIKASI}

Hasil penelitian ini memberikan beberapa implikasi terhadap proses pembelajaran pada mahasiswa baru jurusan bahasa. Implikasi yang pertama adalah penambahan frequency latihan pada mereka yang dapat dilakukan secara integrated pada matakuliah-matakuliah untuk meningkatkan kemampuan kosakata mereka. Yang kedua dan terpenting adalah penggunaan bahasa pengantar yang sesuai dengan level mereka. Latsanyphone, s \& Bouangeune, s (2009) dalam sebuah studi eksperimental pada mahasiswa dengan level kemampuan rendah di laos menghasilkan bahwa intervensi bahasa ibu terhadap pembelajaran kosakata bahasa inggris di universitas memberikandampak yang positif bagi mahasiswa. Lebih lanjut dijelaskan hal ini kemungkinan karena jelasnya pemahaman mereka melalui bahasa ibu. Dengan kata lain penggunaan bahasa pengantar selain bahasa inggris di mungkinkan ketika peserta didik membutuhkan pemahaman. Ini biasa terjadi pada mereka dengan level vocabulary yang rendah.

\section{REFERENSI}

Barnhart, Cynthia A. 2008. The Facts On File Student's Dictionary of American English. Facts on File, Inc

Diyanti, Y.B. (2003). Computer Assisted Language Learning: Teaching Vocabulary Using Blog. 1. Retrieved on January 05,2020 at 10.00 a.m. fromhttp://staffnew.uny.ac.id/upload/ 132310012/penelitian/tc-vocab-blognw.pdf

Fakhruddin and Fakhruddin \& jamaris, m. M. 2005. Increased Mastery of English Vocabulary Through

Games.Vol 3.No. 2.1-41. Retrived on

February19 ${ }^{\text {th }}, 2017$
Harmer, J. (2001). The Practice of English Language Teaching. London: Longman

Latsanyphone, s \& Bouangeune, s, 2009 Using L1 in Teaching Vocabulary to Low English Proficiency Level Students: A Case Study at the National University of Laos. English language teaching CC senet Journal. Retrieved on september 14, 2020 at 15.30

Nation, I.S.P. 1983. Testing and teaching vocabulary. Guidelines 5, no. 1: 12-25

Schmitt, N., D. Schmitt, and C. Clapham. 2001. Developing and exploring the behaviour of two new versions of the vocabulary levels test. Language Testing 18, no. 1: 55-88.

Soedjito, 2009.Indonesian Vocabulary. Jakarta: GramediaPustakaUtama

Thornburry, S. (2002). How to Teach Vocabulary 5th Ed: Essex: Pearson Education Limıu. 